\title{
Jurnal

\section{PERBEDAAN KEJADIAN DEPRESI PADA PRIA DAN WANITA PADA LANSIA YANG MENDERITA DIABETES MELLITUS}

\section{The Diferences Depression in Man and Women Elderly who Have Diabetes Mellitus}

\author{
Nur Ainiyah, Iis Noventi, Chilyatiz Zahroh
}

Universitas Nahdlatul Ulama Surabaya

\section{Riwayat artikel}

Diajukan: 6 Februari 2021

Diterima: 23 Februari 2021

\section{Penulis Korespondensi:}

- Nur Ainiyah

- Universitas Nahdlatul Ulama Surabaya

e-mail:

ainiyahannuri@unusa.ac.id

\section{Kata Kunci:}

man, women, depression, elderly

\section{Abstrak}

Pendahuluan: Diabetes Mellitus (DM) merupakan penyakit metabolik yang terjadi secara kronis karena gangguan pada insulin dan mempunyai berbagai komplikasi pada penderitanya, baik akut maupun kronik. Penurunan kemampuan fisik, emosional, social ditambah dengan gangguan metabolism dan komplikasinya membuat lansia mengalami depresi yang bermanifestasi pada kualitas tidur lansia. Tujuan penelitian ini adalah untuk mengetahui perbedaan kejadian depresi pada pria dan wanita pada lansia yang menderita dibetes mellitus. Metode: dalam penelitian ini adalah komparatif. Populasi penelitian ini adalah seluruh lansia di Wilayah X sebanyak 60 lansia terdiri dari 27 lansia pria dan 33 lansia wanita. Sampel dalam penelitian ini adalah penelitian berjumlah 60 anggota, dengan menggunkan total sampling/ Pengumpulan data depresi dilakukan dengan pemberian kuesioner berdasarkan skala depresi Beck. Analisis data yang digunakan Skor depresi lansia pada pria dan lansia wanita yang terkumpul dari hasil pengumpulan data akan diukur perbedaannya dengan uji beda dua mean (T-test). Hasil: Hasil penelitian menunjukkan rata-rata skor depresi pria $=1.59$ dan standart deviasi $=1.575$ dan ratarata skor depresi wanita $=3.54$ standart deviasi adalah 1.96 , Tingkat signifikansi $(\mathrm{p}=0,001 ; \mathrm{p}<0.05)$, sehongga $\mathrm{Hal}$ ini menunjukkan perbedaan yang bermakna antara depresi pada lansia pria dan wanita yang menderita DM Kesimpulan: diharapkan semua anggota keluarga lansia sebagai salah satu support system bagi lansia dapat memberikan dukungannya sehingga lansia tidak mengalami depresi

\section{Abstract}

Background. Diabetes Mellitus (DM) is a metabolic disease that occurs chronically due to interference with insulin and has various complications for sufferers, both acute and chronic. Decreased physical, unstable emotional, interaction of social abilities decrease, anda also metabolic disorders and its complications make the elderly had depression which is manifested in the quality of sleep of the elderly.Objective: The purpose of this study was to determine the differences in the incidence of depression in men and women in the elderly who suffer from diabetes mellitus. Analytical research design with cross sectional design in 4 villages between Kenjeran Village, Bulak Village, Kedung Cowek Village, and Sukolilo Village. Data retrieval is done by questionnaire sheet and observation using microtoise, sample technique uses Sampling Probability by using Stratified Random Sampling as many as 152 children. Results: The results showed the mean depression score for men $=1.59$ and the standard deviation $=1.575$ and the mean depression score for women $=3.54$ the standard deviation was 1.96, the level of significance $(p=0.001 ; p<0.05)$. Its shows a significant difference between depression in elderly men and women who suffer from DM. Conclusion: Therefore, it is expected that all members of the elderly family as one of the support systems for the elderly can provide support so that the elderly do not experience depression. 


\section{PENDAHULUAN}

Lanjut usia merupakan tahap akhir dari siklus kehidupan manusia. Proses menua merupakan proses yang menunjukkan kemunduran pada fungsi fisik manusia, perubahan emosional, begitu pula dengan interaksi sosial sedikit demi sedikit akan mengalami perubahan. Diabetes Mellitus (DM) merupakan penyakit metabolik yang terjadi secara kronis karena gangguan pada insulin dan mempunyai berbagai komplikasi pada penderitanya, baik akut maupun kronik. Penurunan kemampuan fisik, emosional, social ditambah dengan gangguan metabolism dan komplikasinya membuat lansia mengalami depresi yang bermanifestasi pada kualitas tidur lansia (Hurlock, 2010)

Angka kejadian depresi lansia di dunia terjadi antara 8 sampai $15 \%$ dan studi lain menyatakan bahawa gejala-gejala depresi terjadi kurang lebih 10 sampai $15 \%$ pada lansia yang berusia > 65 tahun,sedangkan depresi ringan sampai sedang terjadi pada kurang lebih 50-75\% lansia, sedangkan depresi berat terjadi pada 10-20\% lansia. Dengan demikian depresi menjadi masalah kesehatan jiwa yang signifikan di masayarakt terutama lansia.(Kurnianto, Purwaningsih, \& Nihayati, 2019)

Berdasarkan data Badan Pusat Statistik (BPS, 2018)menunjukkan bahwa Jawa Timur menempati urutan kedua yang memiiki proporsi penduduk berstruktur tua (lansia) jauh berada diatas patokan dan Estimasi tahun 2022 lansia akan mengalami peningkatan sekitar 30 - 40 juta orang. Peningkatan ini seiring dengan peningkatan $50 \%$ dari lansia yang sedang loneliness. Hal ini yang memicu terjadinya depresi. Menurut (Sucipto \& Rinawati, 2021) bahwa tidak ada perbedaan yang siginifikan. kejadian depresi pada laki laki dan wanita lansia dengan $p$ valaue 0,452 . Berbeda dengan penelitian (Aryawangsa \& Ariastuti, 2016). Kejadian depresi cenderung dialami oleh laki-laki (30,6\%), kelompok usia â\%o 70 tahun $(30,6 \%)$, tingkat pendidikan rendah $(24,4 \%)$, tidak bekerja $(25,4 \%)$, tingkat penghasilan perbulan rendah $(41,2 \%)$, tidak menikah (50\%), memiliki penyakit kronis $>2$ $(28,6 \%)$, dan tidak memiliki riwayat keluarga depresi $(23,9 \%)$. Prevalensi lansia dengan depresi cenderung lebih tinggi pada lansia laki-laki, kelompok usia 70 tahun ke atas, berpendidikan rendah, tidak bekerja, berpenghasilan perbulan rendah, tidak menikah, memiliki penyakit kronis $>2$, dan tidak memiliki riwayat keluarga depresi, akan tetapi tidak dijelaskan secra spesifik penyakit kronis yang diderita respondennya,

Gambaran klinis depresi pda lansia ditemukan secra tidak khas. Depresi pada lansia lebih menunjukkan keluhan-keluhan. Keluhan ini dapat berupa keluhan somatis, antara lain kelelahaan, kualitas tiduryang tidak optimal, berat badan yang turun, cemas atau penurunan kemampuan lainnya. Penderita diabetes mellitus beresiko berkurangnya angka harapan hidup apalagi ditambah lagi dengan adanya kemunduran fisik pada lansia. Jika depresi ini dibiarkan maka kemmapuan fiansial lansia dan keluarga yang menurun, pemenuhan fungsi social lansia juga akan menurun, bahkan bisa sampai terjadi bunuh diri akibat dari depresi berat yang tidak tertangani (Stanley dalam Kurnianto, 2011).

Solusi yang dapat dilakukan untuk meminimalkan depresi dibagi menjadi 2 macam. Pertama yaitu berasal motivasi lansia itu sendiri kedua yaitu support system sperti dari keluarga, teman,tetangga serta masyarakat. Motivasi diri dari lansia dapat dialkukan dnegan melakukan interaksi dengan sosial masyarakat dan selalu positive thingking terhadap segala yang terjadi

\section{METODE}

Metode dalam penelitian ini adalah komparatif bertujuan untuk membandingkan depresi pada laki-laki dan perempuan yang menderita diabetes mellitus.

Populasi penelitian ini adalah seluruh lansia di Wilayah X sebanyak 60 lansia terdiri dari 27 lansia pria dan 33 lansia wanita. Sampel dalam penelitian ini adalah penelitian berjumlah 60 anggota, dengan menggunkan total sampling. Pengumpulan data dikumpulkan setelah peneliti melakukan perijinan kepada kepala Wilayah $\mathrm{X}$ dan responden menyatakan bersedia menjadi responden melalui pengisian informed consent Variabel depresi pada lansia diukur dengan kuesioner berdasarkan skala depresi Beck. Analisis data yang digunakan skor depresi lansia pada pria dan lansia wanita yang terkumpul dari hasil pengumpulan data akan 
diukur perbedaannya dengan uji beda dua mean (T-test).

\section{HASIL DAN PEMBAHASAN}

Tabel 1 Karakteristik Responden di Wilayah X

\begin{tabular}{lcccc}
\hline \multirow{2}{*}{ Karakteristik } & \multicolumn{4}{c}{ Jenis Kelamin } \\
\cline { 2 - 5 } & \multicolumn{2}{c}{ Pria } & \multicolumn{2}{c}{ Wanita } \\
\cline { 2 - 5 } & $\mathrm{f}$ & $\%$ & $\mathrm{f}$ & $\%$ \\
\hline Pendidikan & & & & \\
Tidak & 11 & 41 & 17 & 52 \\
Sekolah & & & & \\
SD & 12 & 44 & 11 & 33 \\
SMP & 1 & 4 & 4 & 12 \\
SMA & 3 & 11 & 0 & 0 \\
PT & 0 & 0 & 1 & 3 \\
\hline Pekerjaan & & & & \\
Bekerja & 12 & 44 & 13 & 39 \\
Tidak & 15 & 56 & 20 & 61 \\
Bekerja & & & & \\
\hline Pernikahan & \multicolumn{4}{c}{} \\
Menikah & 14 & 52 & 12 & 36 \\
Janda/Duda & 13 & 48 & 21 & 44 \\
\hline Penyebab Kehilangan Pasangan & \\
Perceraian & 3 & 23 & 1 & 5 \\
Kematian & 10 & 77 & 2095 & \\
\hline Kegiatan Masyarakat & & \\
Aktif & 7 & 26 & 4 & 12 \\
Tidak Aktif & 20 & 74 & 29 & 88 \\
\hline
\end{tabular}

Berdasarkan tabel 1 diketahui bahwa hampir separuh lansia, lebih dari separuh berpendidikan SD, lebih dari separuh tidak bekerja dan menikah, sebagian besat tidak aktif dalam kegiatan masyarakat.

Tabel 2 Karakterisik Responden Menurut Umur di Wilayah X

\begin{tabular}{cccccc}
\hline Umur & Mea & Media & Modu & SD & CI 95\% \\
& & \multicolumn{2}{c}{1} & & \\
\hline Pria & 65,7 & 62 & 60 & 6,4 & $63,17-$ \\
& & & & & 68,2 \\
& & & & 4 \\
Wanit & $66,0 \backslash$ & 64 & 60 & 6,1 & $63,87-$ \\
& & & & & 68,2 \\
& & & & & 6 \\
\hline
\end{tabular}

Tabel Tabel 2 : menunjukkan dari 27 responden pria rata-rata umur responden adalah 65,7 tahun dengan median pada umur 62 tahun dan responden paling banyak berumur 60 tahun, sedangkan dari 33 responden wanita rata-rata umur responden adalah 66,06 tahun dengan median pada umur 64 tahun dan responden paling banyak berumur 60 tahun.

Tabel 3 Perbedaan Skor Depresi Pada Pria dan Wanita pada lansia di Wilayah X Uji $T$ test analysis

\begin{tabular}{|c|c|c|c|c|c|c|}
\hline $\begin{array}{l}\text { jenis } \\
\text { kelam } \\
\text { in }\end{array}$ & $\begin{array}{c}\text { Skor } \\
\text { depres } \\
\text { i }\end{array}$ & $\mathrm{N}$ & $\begin{array}{c}\text { Mea } \\
\mathrm{n} \text { I }\end{array}$ & $\begin{array}{l}\text { Std. } \\
\text { Dev }\end{array}$ & $\begin{array}{c}\text { Std. } \\
\text { Erro } \\
\text { r } \\
\text { Mea } \\
\text { n }\end{array}$ & $\begin{array}{c}95 \% \\
\text { Confiden } \\
\text { ce } \\
\text { Interval } \\
\text { of the } \\
\text { Differenc } \\
\text { e }\end{array}$ \\
\hline & & & & & & Low Up \\
\hline Pria & 43 & 27 & $\begin{array}{r}1.59 \\
2\end{array}$ & $\begin{array}{r}1.57 \\
5\end{array}$ & $\begin{array}{r}.303 \\
1\end{array}$ & $\begin{array}{r}1.01 \\
5\end{array}$ \\
\hline $\begin{array}{l}\text { Wanit } \\
\text { a }\end{array}$ & 118 & 33 & $\begin{array}{r}3.54 \\
5\end{array}$ & $\begin{array}{r}1.96 \\
9\end{array}$ & $\begin{array}{r}.342 \\
9\end{array}$ & $\begin{array}{r}1.032 .8 \\
6\end{array}$ \\
\hline
\end{tabular}

Tingkat signifikansi : 0,000

Tabel 3 menunjukkan bahwa menunjukkan bahwa jumlah skor depresi dari 27 responden pria adalah 43 dengan skor minimal 1.051 dan skor maksimal 2.889, rata-rata skor $=1.59$ dan standart deviasi $=1.575$ dan total skor depresi dari 33 responden wanita adalah 118 dengan skor minimal 1.036 dan skor maksimal 2.869, rata-rata skor $=., 54$ dan standart deviasi $=1.96$. Hasil T test menunjukan tingkat signifikansi : 0.000. Hal ini menunjukkan perbedaan yang bermakna antara depresi pada lansia pria dan wanita yang menderita DM

\section{PEMBAHASAN}

Berdasarkan hasil penelitian di Wilayah $\mathrm{X}$ didapatkan jumlah skor depresi dari 27 responden pria adalah 43, rata-rata skor $=1,59$ dan Standart deviasi dari skor depresi pria adalah 1,58 sedangkan jumlah skor depresi dari 27 responden wanita adalah 118 , rata-rata skor $=3.54$ dan standart deviasi dari skor depresi wanita adalah 1.96, dengan hasil $\mathrm{T}$ test yang menunjukkan bahwa tingkat signifikansi 0.00 Hal ini menunjukkan perbedaan yang bermakna antara depresi pad lansia pria dan wanita yang menderita DM, wanita mempunyai rata-rata lebih tinggi terjadinya depresi lebih tinggi daripada pria.

Hal ini disebabkan karena saat lansia orang mengalami berbagai perubahanperubahan bio-psiko-sosial yang cenderung 
mengalami kemunduran dan didukung oleh kematangan kepribadian yang semakin menurun sehingga pada lansia yang kurang bisa beradaptasi akan mudah mengalami kondisi depresi, selain itu pada penderita DM tanda tanda yang diderita seperti sering kencing sering makan, sering minum ditambah dengan keterbatsan kemampuan lansia kan menambah parah terjadinya depresi.

Selain faktor umur, ada beberapa faktor yang mungkin dapat mempengaruhi skor depresi pada lansia. Salah satunya adalah perbedaan karakteristik, hal ini sesuai pendapat (Babatsikou et al., 2017) yang mengatakan bahwa karakteristik pria lebih mengedepankan rasional daripada emosional sehingga dalam menghadapi suatu masalah atau stressor lebih matang emosinya dibandingkan dengan wanita.sedangkan wanita lebih emosional dan lebih memikirkan masalah yang terjadi padanya. Hal ini sesuai pendapat (Johnson \& Whisman, 2013)yang mengatakan bahwa karakteristik wanita lebih wanita lebih mengedepankan emosional daripada rasional dan dalam menghadapi masalah lebih banyak menggunakan perasaan dan mudah cemas sehingga mudah jatuh dalam keadaan depresi. Sehingga mungkin hal ini yang mempengaruhi skor depresi pada lansia wanita mengedepankan emosional kan perasaan dan mudah cemas sehingga mudah jatuh dalam keadaan depresi. Sehingga mungkin hal ini yang mempengaruhi skor depresi pada lansia wanita.

Depresi juga dimungkinkan terjadi karena tingkat pendidikan berpengaruh pada skor depresi lansia wanita. Menurut (Pae, 2017)bahwa pendidikan mencakup seluruh proses kehidupan dan segala bentuk interaksi individu dengan lingkungan baik formal maupun informal. Semakin tinggi pendidikan seseorang, maka akan semakin mudah berinteraksi dengan lingkungan. Sehingga jika menghadapi suatu masalah akan mendapatkan dukungan dari lingkungan lebih banyak dan tidak sampai menimbulkan rasa kesepian yang akhirnya

jatuh pada kondisi depresi. Hal ini dapat dilihat dari tabel 3 yang menunjukkan responden wanita yang berpendidikan rendah (tidak sekolah dan SD) lebih banyak dibandingkan dengan responden wanita yang berpendidikan SMP, SMA dan satupun tidak ada yang berpendidikan sarjana. Sehingga mungkin faktor tingkat pendidikan rendah mempengaruhi juga kemampuan individu dalam menghadapi suatu masalah atau stressor dan kemungkinan mengalami depresi lebih besar.

Kehilangan pasangan hidup dan penyebab kehilangan pasangan hidup mungkin bisa mempengaruhi skor depresi pria. Hal ini dapat dilihat dari hasil tabel 3 yang yang menunjukkan proporsi responden wanita yang berstatus janda (telah kehilangan pasangan hidup) lebih tinggi daripada responden pria yang bersatus duda. Kemudian penyebab kehilangan pasangan paling banyak karena kematian dan pada penyebab kehilangan pasangan hidup karena perceraian proporsi responden pria lebih tinggi dibandingkan dengan wanita. Menurut (Newson, Boelen, Hek, Hofman, \& Tiemeier, 2011) kehilangan pasangan dapat menjadi stressor (kehilangan pasangan hidup karena kematian biasanya lebih berpengaruh dibandingkan dengan perceraian). Hal ini dikarenkan suami atau istri adalah support system seorang penderita DM untuk minum obat, untuk berasabar menrima kondisi sakitnya, akan tetapi hal ini tergantung kemampuan seseorang dalam mengahadapi stressor tersebut, sehingga mungkin karena karakteristik wanita yang dalam menghadapi masalah cenderung lebih banyak mengunakan perasaan, sulit beradaptasi dengan perubahan yang terjadi saat lansia terutama kehilangan pasangan hidup dibandingkan dengan lansia pria seseorang dalam mengahadapi stressor tersebut sehingga terjadinya depresi berkepanjangan.

Keikutsertaan dalam jaringan sosial berkaitan dengan aktivitas sosial yang diikuti oleh individu seperti aktif dalam pertemuanpertemuan sosial atau organisasi yang ada dimasyarakat mungkin juga dapat berpengaruh pada skor depresi lansia pria. Hal ini dapat dilihat dari hasil tabel 3 yang menunjukkan responden pria yang tidak aktif dalam kegiatan masyarakat lebih tinggi.

Menurut pendapat (Nguyen, Chatters, Taylor, \& Mouzon, 2016) semakin luas jaringan individu tersebut dalam masyarakat maka individu tersebut akan lebih mendapat dukungan sosial jika menghadapi suatu masalah atau stressor. Sehingga mungkin dengan kurangnya dukungan sosial yang didapat akan menyebabkan seseorang lebih mudah mengalami depresi Begitu pula Menurut 
pendapat (Miranda, Soares, \& Silva, 2016)semakin luas jaringan individu tersebut dalam masyarakat maka individu tersebut akan lebih mendapat dukungan sosial jika menghadapi suatu masalah atau stressor. Sehingga semakin seseorang Jadi jika individu tidak atau kurang aktif dalam kegiatan yang ada dimasyarakat, semakin sedikit pula dukungan sosial yang diberikan jika menghadapi masalah. Sehingga individu seperti terkucil dari masyarakat dan perasaan terkucil dan kesepian.

\section{KESIMPULAN}

Depresi merupakan gangguan kejiwaan yang banyak berkaitan dengan penyakit kronis. Individu dengan diabetes mellitus (DM) beresiko tinggi untuk mengalami depresi terutama terjadi pada wanita. Oleh karena itu diharapkan semua anggota keluarga lansia sebagai salah satu support system bagi lansia dapat memberikan dukungannya sehingga lansia tidak mengalami depresi atau berkurang tidangkat depresinya

\section{DAFTAR PUSTAKA}

BPS. (2018). Statiik Penduduk Lanjut Usia. Jawa Timur: Badan Pusat Statistik

Hurlock, E. (2010). Psikologi Perkembangan . Jakarta: Erlangga

Muhith, A. d. (2016). S. (2016). Pendidikan Keperawatan Gerontik. Yogyakarta: ANDI.

Johnson, D. P., \& Whisman, M. A. (2013). Gender differences in rumination: A metaanalysis. Personality and Individual Differences, 55(4), 367-374. https://doi.org/10.1016/j.paid.2013.03.019

Kurnianto, S., Purwaningsih, \& Nihayati, H. E. (2019). Penurunan tingkat depresi pada lansia dengan pendekatan bimbingan spiritual. Jurnal Ners, 6(2), 156-163.

Miranda, L. C. V., Soares, S. M., \& Silva, P. A. B. (2016). Quality of life and associated factors in elderly people at a reference center. In Ciencia e Saude Coletiva (Vol. 21). https://doi.org/10.1590/1413812320152111.21352015

Newson, R. S., Boelen, P. A., Hek, K., Hofman, A., \& Tiemeier, H. (2011). The prevalence and characteristics of complicated grief in older adults. Journal of Affective Disorders, 132(1-2), 231-238. https://doi.org/10.1016/j.jad.2011.02.021

Nguyen, A. W., Chatters, L. M., Taylor, R. J., \& Mouzon, D. M. (2016). Social Support from Family and Friends and Subjective Well-Being of Older African Americans. Journal of Happiness Studies, 17(3), 959979. https://doi.org/10.1007/s10902-0159626-8

Sucipto, S., \& Rinawati, F. (2021). Perbedaan Depresi Lansia di Pondok Lansia dan Lansia di Posbindu. Jurnal Ilmiah Permas: Jurnal Ilmiah STIKES Kendal, 43-48

Pae, K. (2017). Perbedaan Tingkat Depresi Pada Lansia Yang Tinggal Di Panti Werdha Dan Yang Tinggal Di Rumah Bersama Keluarga. Jurnal Ners Lentera, 5(1), 21-32.

Roy T., Lloyd CE. Epidemiology of depression and diabetes: a systematic review. J Affect Disord. 2012;142(Suppl):S8-2

Utami, A. W., Gusyaliza, R., \& Ashal, T. (2018). Hubungan Kemungkinan Depresi dengan Kualitas Hidup pada Lanjut Usia di Kelurahan Surau Gadang Wilayah Kerja Puskesmas Nanggalo Padang. Jurnal Kesehatan Andalas, 7(3), 417. https://doi.org/10.25077/jka.v7i3.896 